\title{
Manajemen Dakwah Lembaga Dakwah Kampus Unit Pengkajian Mahasiswa Islam (LDK-UPMI) IAIN Kendari
}

\author{
Samsu ${ }^{1}$, Mansur $^{2}$ \\ ${ }^{1}$ Institut Agama Islam Negeri (IAIN) Kendari \\ ${ }^{2}$ Institut Agama Islam Negeri (IAIN) Kendari \\ Emai:drs.syamsu.mpd@gmail.com ;mansurrahman44@gmail.com
}

\begin{abstract}
Dakwah is an individual obligation of every Muslim that makes students feel called to take part in it. They embed themselves in the LDK UPMI IAIN Kendari. They manage their dakwah well in accordance with the basic principles of modern management. The missionary institution of the campus actively regenerates and fosters missionary bearers so that regeneration can be created sustainably. Campus dakwah institutions are student organizations that receive funding support from institutions. The research question is how to manage LDK-UPMI IAIN Kendari dakwah. The data of this study were collected through observation and interviews and documentation. The findings of this study are that LDK dakwah IPM Kendari's dakwah management has fully run according to the basic concepts and management principles, namely: a. The existence of Da'wah planning; $b$. organizing dakwah; c. missionary movement d. preaching supervision.
\end{abstract}

Key words: Campus Dakwah Institution, Management, Kendari

\begin{abstract}
Abstrak
Dakwah merupakan kewajiban individu setiap muslim yang menjadikan para mahasiswa merasa terpanggil untuk mengambil bagian di dalamnya. Mereka mewadahi diri dalam LDK UPMI IAIN Kendari. Mereka mengelola dakwah mereka secara baik sesuai dengan psinsip-prinsip dasar manajemen moderen. Lembaga dakwah kampus ini secara aktif melakukan regenerasi dan pembinaan insan-insan pengemban dakwah sehingga regenerasi dapat tercipta secara berkelanjutan. Lembaga dakwah kampus merupakan organ kemahasiswaan yang mendapat support dana dari institusi. Pertanyaan penelitian ini adalah bagaimana menajemen dakwah LDK-UPMI IAIN Kendari. Data penelitian ini dikumpulkan memlalui observasi dan wawancara dan dokumentasi. Temuan penelitian ini adalah bahwa manajemen dakwah LDK UPMI IAIN Kendari telah sepenuhnya berjalan sesuai konsep dan peinsip dasar manajemen Yakni : a. Adanya perencanaan Dakwah; b. pengorganisasian dakwah; c. pergerakan dakwah d. pengawasan dakwah.
\end{abstract}

Kata kunci : Lembaga Dakwah Kampus, Manajemen, Kendari.

Al-Munzir Vol. 12. No. 1 Mei 2019 


\section{A. Pendauluan}

Aktivitas dakwah muncul sejak Islam dihadirkan Allah kepada manusia. Dakwah berarti; penyiaran, propaganda, seruan untuk mempelajari dan mengamalkan ajaran Islam. Dakwah juga bermakna sebagai suatu proses mengubah situasi kepada situasi lain yang lebih baik sesuai ajaran Islam atau suatu proses mengajak manusia ke jalan Allah Swt (Muh.Arifin, 2006 : 5).

Dakwah Islam adalah mengajak manusia dengan cara kebijaksanaan kepada jalan yang benar sesuai dengan perintah Tuhan, untuk kemaslahatan dan kebahagiaan mereka di dunia dan akhirat (Thoha Yahya Omar ; 1971 ; 1). Lapangan dakwah meliputi semua aktivitas manusia secara totalitas, sebagai individu, sebagai anggota masyarakat, bahkan sebagai makhluk alam semesta. Orang yang mengaku sebagai muslim, maka dia menjadi seorang juru dakwah. Dakwah dalam arti amar ma'ruf nahi munkar, merupakan syarat mutlak bagi kesempurnaan dan keselamatan hidup manusia.

Kewajiban dakwah adalah kewajiban individu yang memiliki pembawaan fitrah sebagai mahluk sosial. Dakwah haruslah bermuarah untuk memperbaiki suasana kehidupan manusia, sesuai dengan kehendak dan tuntutan kebenaran. Dakwah merupakan ajakan, dorongan atau panggilan kepada umat manusia untuk menyebarluaskan Islam dan merealisir ajarannya di tengah masyarakat agar mereka memeluk Islam dan mengamalkannya.

Saat ini kita jumpai berbagai aktivitas gerakan-gerakan yang berusaha untuk menyampaikan dakwah di tengah umat, tidak terkecuali mahasiswa yang dianggap sebagai kaum intelektual dan mempunyai potensi besar untuk melakukan perubahan di tengah-tengah masyarakat serta menyadarkan umat dari berbagai keterpurukan yang menimpanya. Namun, kita tidak dapat menutup mata melihat fenomena pada kalangan pemuda saat ini khususnya kaum mahasiswa yang tidak lagi identik dengan keberadaan idealismenya sebagai sumber perubahan (agent of change) dan (agent sosial of control) disebabkan pemahaman keislamannya dangkal sehingga pandangannya tidak sampai pada keyakinan bahwa Islam adalah ideologi yang mencakup kehidupan, manusia dan alam semesta serta kaitannya sebelum dan sesudah kehidupan, pada akhirnya tidak mampu memberikan solusi (problem solving) yang tepat dalam mengatasi Al-Munzir Vol. 12. No. 1 Mei 2019 
masalah baik dalam masyarakat maupun dikalangan mahasiswa itu sendiri dan juga melahirkan aksi-aksi mahasiswa yang besifat sporadis dan temporal, sebagaimana yang sering ditayangkan baik media elektonik maupun media cetak pada setiap harinya dan senantiasa diwarnai kasus mahasiswa mulai dari tawuran antar perguruan tinggi, narkoba, seks bebas, sampai kepada aksi demonstrasi yang berujung bentrok.

Melihat fenomena diatas, Lembaga Dakwah Kampus (LDK-UPMI) IAIN Kendari, Sebagai salah satu lembaga kemahasiswaan di IAIN Kendari, tentulah berperan penting dalam menanamkan ideologi Islam Dasar Pemikiran Islam (Qiyadah Fikriyah Al-Islamiyah) terhadap mahasiswa IAIN Kendari khususnya dan seluruh mahasiswa pada umumnya dalam pembinaan intensif (Halaqoh) yang pada akhirnya membentuk kepemimpinan berfikir (Qiyadah Fikriyah) yang Islami dan agar pemahaman keislamannya itu dalam mengkaji Islam dapat mengurangi potensi untuk melakukan perbuatan yang tidak sesuai dengan Islam. Namun dalam situasi kampus tentulah mad'u yang dihadapi adalah orang-orang terdidik serta mempunyai tingkat kemampuan untuk diajak berfikir lebih kritis dibandingkan masyarakat biasa (awam) olehnya itu dipandang perlu mempunyai cara-cara tertentu untuk mengarahkan dakwah kesebuah titik, dimana akan terjalin komunikasi yang massif diantara pengembang dakwah. Penyatuan visi-misi dakwah dalam sebuah wadah yang dimaksud di atas adalah organisasi yang berada di bawah naungan Perguruan Tinggi Agama Islam (PTAI) mencakup organisasi kemahasiswaan dalam rangka pembinaan terhadap pola fikir (tsaqofah) dan pola sikap (nafsiah) mahasiswa sehingga mendorong terbentuknya asas berfikir Islami bagi setiap mahasiswa yang berkiprah di dalamnya. Inilah yang menjadi daya tarik bagi para mahasiswa terhadap LDK_UPMI hingga kini memiliki anggota sebanyak 617 anggota.

Demikian hal itu, perlu diketahui pengaruh Lembaga Dakwah Kampus dalam membentuk generasi Islam yang mempunyai pemahaman Islam sebagai ideologi serta menanamkannya dan mampu mengklasifikasi proritas perjuangannya, maka atas dasar inilah akan dikaji bagaimana Menagemen Dakwah LDK-UPMI IAIN Kendari dalam membentuk pemikiran mahasiswa khususnya kader organisasi Lembaga Dakwah Kampus Unit Pengkajian Al-Munzir Vol. 12. No. 1 Mei 2019 
Mahasiswa IAIN Kendari (LDK-UPMI IAIN KENDARI), yang memiliki cara pandang khas terhadap Islam yakni pemikiran dasar Islam dalam bentuk aqidah yang melahirkan pemikiran ideologis sehingga meyakini bahwa Islam merupakan solusi tuntas (problem solving) dalam menyelesaikan setiap problematika umat yang muncul dewasa ini.

\section{B. Metode Penelitian}

Jenis penelitian ini adalah deskriptif kualitatif Data penelitian ini dikumpulkan memlalui observasi,wawancara dan dokumentasi.

\section{Pembahasan}

\section{A. Menajemen Dakwah}

Manajemen dakwah adalah terminologi yang terdiri dari dua kata, yakni manajemen dan dakwah. Kedua kata ini berangkat dari dua disiplin ilmu yang berbeda sama sekali. Istilah yang pertama, berangkat dari disiplin ilmu yang sekuler, yakni Ilmu Ekonomi. Ilmu ini diletakan di atas paradigma materialistis. Prinsipnya adalah dengan modal yang sekecil-kecilnya untuk mendapatkan keuntungan yang sebesar-besarnya. Sementara itu istilah yang kedua berasal dari lingkungan agama, yakni Ilmu Dakwah. Ilmu ini diletakan di atas prinsip, ajakan menuju keselamatan dunia dan akhirat, tanpa paksaan dan intimidasi serta tanpa bujukan dan iming-iming material. Ia datang dengan tema menjadi rahmat semesta alam.

Secara sederhana H. Zainal Muchtarom (1996 : 35) mendefenisikan bahwa manajemen adalah upaya mengatur dan mengarahkan berbagai sumber daya, mencakup manusia (man), uang (money), barang (material), mesin (machine), metode (methode) dan pasar (market). Namun, secara khusus definisi manajemen, sebagaimana yang dikemukakan oleh G.R. Terry bahwa "Management is a distinct process of planing, organizing, actuating, and controlling, perform to determine and accomplish stated objektives by the use of human beings and other resources." (G. R. Terry,1972: 4).

Definisi di atas memberikan gambaran bahwa manajemen itu mengandung arti proses kegiatan. Proses tersebut dimulai dari perencanaan, pengorganisasian, 
pelaksanaan dan pengawasan dengan menggunakan sumber daya lainnya. Seluruh proses tersebut ditujukan untuk mencapai tujuan yang telah ditetapkan.

Demikian juga dengan pendapat (Maluyu S.P. Hasibuan, 2009), beliau menjelaskan bahwa manajemen berasal dari kata to manage yang artinya mengatur. Jadi, Manajemen itu adalah suatu proses untuk mewujudkan tujuan yang diinginkan. Sedangkan menurut Brantas bahwa manajemen adalah suatu proses atau kerangka kerja yang melibatkan bimbingan atau pengarahan suatu kelompok orang ke arah tujuan-tujuan organisasi atau maksud-maksud nyata (Brantas, 2009:4). Dengan demikian maka manajemen adalah ilmu dan seni yang mengatur proses pemamfaatan sumber daya manusia secara efektif, dengan didukung oleh sumber-sumber lainnya dalam suatu organisasi untuk mencapai tujuan.

Menurut James A.F. Stoner bahwa Manajemen adalah suatu proses perencanaan, pengorganisasian, kepemimpinan dan pengendalian upaya dari anggota organisasi serta penggunaan sumua sumber daya yang ada pada organisasi untuk mencapai tujuan organisasi yang telah ditetapkan sebelumnya. Selain itu, Buchari Zainun: "Manajemen adalah penggunaan efektif daripada sumber-sumber tenaga manusia serta bahan-bahan material lainnya dalam rangka mencapai tujuan yang telah ditentukan itu." Demikian pula Oey Liang Lee dalam (RB. Khatib Pahlawan Kayo,2007:17), mengatakan manajemen adalah seni dan ilmu perencanaan, pengorganisasian, pengarahan, pengkoordinasian, dan mengontrolan dari human dan natural resources. Sedangkan James A.F. Stoner: menjelaskan bahwa manajemen adalah proses perencanaan, pengorganisasian dan penggunaan sumberdaya organisasi untuk mencapai tujuan organisasi.

Sama dengan istilah manajemen, menurut (Abdul Aziz,1997:26) bahwa istilah dakwah pun diberi definisi bervariasi oleh para ahli. Dakwah secara bahasa (etimologi) merupakan sebuah kata dari bahasa Arab dalam bentuk masdar. Kata dakwah berasal dari kata: دعا-يدعو-دعوة (da'a, yad'u, da'watan) yang berarti seruan, panggilan, undangan atau do'a. Menurut Abdul Aziz, secara etomologis dakwah berarti: memanggil, menyeru, menegaskan atau membela sesuatu, perbuatan atau perkataan untuk menarik manusia kepada sesuatu, memohon dan meminta, atau do'a. Artinya proses penyampaian pesan-pesan tertentu berupa Al-Munzir Vol. 12. No. 1 Mei 2019 
ajakan, seruan, undangan, untuk mengikuti pesan tersebut atau menyeru dengan tujuan untuk mendorong seorang supaya melakukan cita-cita tertentu (Ahmad Subandi, 1994:10). Oleh karena itu, dalam kegiatanya ada proses mengajak, disebut da'i dan orang yang diajak disebut mad'u.

Berdasarkan beberapa kategori definisi dakwah di atas, maka dapatlah disimpulkan bahwa dakwah Islam pada dasarnya merupakan: (1) perilaku muslim dalam menjalankan Islam sebagai agama dakwah, yang dalam prosesnya melibatkan unsur da'i, pesan dakwah, metode dakwah, media dakwah, mad'u (sasaran dakwah) dalam tujuannya melekat cita-cita ajaran Islam yang berlaku sepanjang zaman dan di setiap tempat; dan (2) proses transmisi, transformasi, dan difusi serta internalisasi ajaran Islam.

Demikian juga dengan pendapat yang dikemukakan M. Munir (2009: 36), beliau memberi komentar bahwa manajemen dan dakwah itu sendiri yaitu sebuah pengaturan secara sistematis dan koordinatif dalam kegiatan atau aktivitas dakwah yang dimulai dari sebelum pelaksanaan sampai akhir dari kegiatan dakwah.

\section{C.2 Tujuan Manajemen Dakwah}

Tujuan adalah sesuatu yang ingin dicapai melalui proses manajemen. Pengertian tujuan dan sasaran hampir sama, tujuan maknanya hasil yang umum sedangkan sasaran berarti hasil yang khusus. Tujuan adalah hasil yang diinginkan yang melukiskan skop yang jelas, serta memberikan arah kepada usaha-usaha seorang manajer.

Tujuan yang ingin dicapai selalu ditetapkan dalam suatu rencana, karena itu hendaknya tujuan ditetapkan "jelas, realistis dan cukup menantang berdasarkan analisis data, informasi dan pemilihan dari alternatif-alternatif yang ada. ( $\mathrm{H}$. Malayu Hasibuan, 2009:17-19).

Tujuan utama dakwah menurut (Abd. Rosyad Shaleh ; 1997 ; 21) adalah nilai atau hasil akhir yang ingin dicapai dan diperoleh oleh keseluruhan tindakan dakwah yaitu Kebahagiaan dan kesejahteraan hidup di dunia dan di akhirat yang diridhai oleh Allah Swt. Secara khusus tujuan dakwah. Menurut Asmuni Syukir, 1983: 49) adalah: 
(1) Mengajak umat manusia yang sudah memeluk islam untuk selalu meningkatkan taqwanya kepada Allah swt. (2) Membina mental agama islam bagi kaum yang masih mualaf. (3) Mengajak umat manusia yang belum beriman agar beriman kepada Allah (memeluk agama Islam). (4)Mendidik dan mengajar anakanak agar tidak menyimpang dari fithrahnya.

Sementara itu M. Natsir, mengemukakan, bahwa tujuan dari dakwah itu adalah (1) Memanggil kita pada syarita, untuk memecahkan persoalan hidup, baik persoalan hidup perseorangan atau persolanan rumah tangga, berjamaah masyarakat, berbangsa-bersuku bangsa, bernegara dan berantar-nergara. (2) Memanggil kita pada fungsi hidup sebagai hamba Allah di atas dunia yang terbentang luas yang berisikan manusia secara heterogen, bermacam karakter, pendirian dan kepercayaan, yakni fungsi sebagai syuhada'ala an-naas, menjadi pelopor dan pengawas manusia. (3) Memanggil kita kepada tujuan hidup yang hakiki, yakni menyembah Allah.

Tujuan dakwah secara umum adalah mengubah perilaku sasaran agar mau menerima ajaran Islam dan mengamalkannya dalam kehidupan sehari-hari, baik yang bersangkutan dengan masalah pribadi, keluarga maupun sosial kemasyarakatnya, agar mendapatkan keberkahan dari Allah Swt. Sedangkan tujuan dakwah secara khusus dakwah merupakan perumusan tujuan umum sebagai perincian daripada tujuan dakwah.

Akhirnya, dapat disimpulkan bahwa secara umum tujuan dan kegunaan manajemen dakwah adalah untuk menuntun dan memberikan arah agar pelaksanaan dakwah dapat diwujudkan secara professional dan proporsional. Dan pada hakikatnya tujuan manajemen dakwah disamping memberikan arah juga dimaksudkan agar pelaksanaan dakwah tidak lagi berjalan secara konvensional seperti tabligh dalam bentuk pengajian dengan tatap muka tanpa pendalaman materi, tidak ada kurikulum, jauh dari interaksi yang dialogis dan sulit untuk dievaluasi keberhasilannya.

\section{C.3 Fungsi Manajemen}

Fungsi manajemen adalah elemen-elemen dasar yang akan selalu ada dan melekat di dalam proses manajemen yang akan dijadikan acuan oleh manajer dalam melaksanakan kegiatan untuk mencapai tujuan. Pada umumnya ada empat Al-Munzir Vol. 12. No. 1 Mei 2019 
4 fungsi manajemen yang banyak dikenal masyarakat yaitu fungsi perencanaan (planning), fungsi pengorganisasian (organizing), fungsi pengarahan (directing) dan fungsi pengendalian (controlling). Untuk fungsi pengorganisasian terdapat pula fungsi staffing (pembentukan staf). Para manajer dalam organisasi perusahaan bisnis diharapkan mampu menguasai semua fungsi manajemen yang ada untuk mendapatkan hasil manajemen yang maksimal.

adapun fungsi-fungsi manajemen adalah : Pertama, Fungsi Perencanaan/Planning adalah suatu kegiatan membuat tujuan perusahaan dan diikuti dengan membuat berbagai rencana untuk mencapai tujuan yang telah ditentukan tersebut. Kedua, Fungsi Pengorganisasian/Organizing adalah suatu kegiatan pengaturan pada sumber daya manusia dan sumberdaya fisik lain yang dimiliki perusahaan untuk menjalankan rencana yang telah ditetapkan serta menggapai tujuan perusahaan. Ketiga,(Fungsi Pengarahan/Directing/Leading adalah suatu fungsi kepemimpinan manajer untuk meningkatkan efektifitas dan efisiensi kerja secara maksimal serta menciptakan lingkungan kerja yang sehat, dinamis, dan lain sebagainya. Keempat, Fungsi Pengendalian/Controling adalah suatu aktivitas menilai kinerja berdasarkan standar yang telah dibuat untuk kemudian dibuat perubahan atau perbaikan jika diperlukan.

\section{C.4 Fungsi Manajemen Dakwah}

Fungsi Manajemen dakwah adalah

(1) Takhthith (Perencanaan Dakwah)

Dalam aktivitas dakwah, perencanaan dakwah bertugas menentukan langkah dan program dalam menentukan setiap sasaran, menentukan sarana-prasarana atau media dakwah, serta personel da'i yang akan diterjunkan. Menentukan materi yang cocok untuk sempurnanya pelaksanaan, membuat asumsi berbagai kemungkinan yang dapat terjadi yang kadang-kadang dapat memengaruhi cara pelaksanaan program dan cara menghadapinya serta menentukan alternatifalternatif, yang semua itu merupakan tugas utama dari sebuah perencanaan. (Ishak Asep, Hendri Tanjung, 2002:19).Sementara itu Rosyad Saleh, menyatakan, bahwa perencanaan dakwah adalah proses pemikiran dan pengambilan keputusan yang matang dan sistematis, mengenai tindakan-tindakan yang akan dilakukan pada masa yang akan datang dalam rangka menyelenggarakan dakwah. 
(2) Tanzhim (Pengorganisasian Dakwah)

adalah seluruh proses pengelompokkan orang-ornag, alat-alat, tugas-tugas, tanggung jawab dan wewenang sedemikian rupa sehingga tercipta suatu organisasi yang dapat digerakkan untuk mencapai tujuan yang telah ditentukan. Sementara itu, Rosyid Saleh mengemukakan bahwa rumusan pengorganisasian dakwah itu adalah "rangkaian aktivita menyusun suatu kerangka yang menjadi wadah bagi setiap kegiatan usaha dakwah dengan jalan membagi dan mengelompokkan pekerjaan yang harus dilaksanakan serta menetapkan dan menyusun jalinan hubungan kerja diantara satuan-satuan organisasi atau petugasnya.

(3)Tawjih (Penggerakan Dakwah) adalah seluruh proses pemberian motivasi kerja kepada para bawahan sedemikian rupa, sehingga mereka mampu bekerja dengan ikhlas demi tercapainya tujuan organisasi dengan efisien dan ekonomis.Motivasi diartikan sebagai kemampuan seorang manajer atau pemimpin dakwah dalam memberikan sebuah kegairahan, kegiatan dan pengertian, sehingga para anggotanya mampu untuk mendukung dan bekerja secara ikhlas untuk mencapai tujuan organisasi sesuai tugas yang dibebankan kepadanya.

(4) Riqaabah (Pengendalian Dakwah) dapat dikatakan sebagai sebuah pengetahuan teoritis praktis. Karena itu, para da;i akan lebih cepat untuk mencernanya jika dikaitkan dengan prilaku dari da'i itu sendiri sesuai dengan organisasi. Dengan demikian, pengendalian manajemen dakwah dapat dikategorikan sebagai bagian dari prilaku terapan, yang berorientasi kepada sebuah tuntutan bagi para da'i tentang cara menjalankan dan mengendalikan organisasi dakwah yang dianggap baik.

Sementara itu Robert J. Mockler mendefinisikan, sebagaimana yang ditulis oleh (M. Munir ; 2009 ; 93-170) bahwa elemen esensial dari proses pengendalian menajemen sebuah standar prestasi kerja dengan tujuan perencanaan, untuk mendesain sistem umpan balik informasi, untuk membandingkan prestasi yang sesungguhnya dengan standar yang telah ditetapkan terlebih dahulu, untuk menetapkan apakah ada deviasi serta untuk mengatur signifikasinya, serta mengambil tindakan yang diperlukan untuk memastikan bahwa sumber daya 
perusahaan telah dilaksanakan secara seefektif dan seefisien mungkin guna mencapai tujuan perusahaan.

\section{C.5. Unsur-unsur Manajemen Dakwah}

Dakwah dalam prosesnya melibatkan unsur-unsur (rukun) dakwah yang terbentuk secara sistematik. Unsur-unsur tersebut;

\section{1) Da'i (Subjek Dakwah)}

Da'i adalah orang yang mengajak orang lain baik secara langsung, melalui lisan, tulisan atau perbuatan untuk mengamalkan ajaran-ajaran Islam atau menyebar luaskan ajaran Islam, melakukan upaya perubahan kearah kondisi yang lebih baik menurut ajaran Islam.

2) Mad'u (objek dakwah)

Mad'u adalah seluruh manusia sebagai makhluk Allah yang dibebani menjalankan agama Islam dan diberi kebebasan untuk berikhtiar, kehendak dan bertanggungjawab atas perbuatan sesuai dengan pilihannya, mulai dari individu, keluarga, kelompok, golongan, kaum, massa, dan umat manusia seluruhnya. (Jamaludin Kafie ;1993 ; 32).

3) Maddah (Pesan Dakwah)

Maddah adalah pesan-pesan, materi atau segala sesuatu yang harus disampaikan oleh da'i kepada mad'u, yaitu keseluruhan ajaran Islam, yang ada di dalam Kitabullah maupun Sunah Rasul-Nya. (Hafi Anshari ; 1993 ; 146).

4) Wasilah (media dakwah)

Wasilah dakwah adalah alat objektif yang menjadi saluran yang dapat menghubungkan ide dengan umat, suatu elemen yang vital dan merupakan urat nadi dalam totalitas dakwah yang keberadaannya sangat urgent dalam menentukan perjalanan dakwah.

5) Thariqah (Metode Dakwah)

Uslub adalah suatu cara dalam melaksanakan dakwah, menghilangkan rintangan atau kendala-kendala dakwah, agar mencapai tujuan dakwah secara efektif dan efisien.

6) Atsar (efek dakwah) 
Atsar sering disebut dengan feed back (umpan balik) dari proses) dakwah ini sering dilupakan atau tidak banyak menjadi perhatian para da'i. Kebanyakan mereka menganggap bahwa setelah dakwah disampaikan, maka selesailah dakwah. Padahal, atsar sangat besar artinya dalam penentuan langkah-langkah dakwah berikutnya.

\section{C.6 Prinsip Manajemen Dakwah}

Islam dalam memandang manajemen berdasarkan teologi, yakni pada dasarnya manusia itu memiliki potensi positif yang dilukiskan dengan istilah hanif. Keterkaitan antara manajemen dan watak hanif ialahwatak hanif akan menyebabkan manusia cenderung untuk memilih yang baik dan benar dalam seluruh kehidupannya. Hal ini dapat ditemukan penjelasannya dalam sebuah Hadits Qudsi yang mengatakan bahwa :

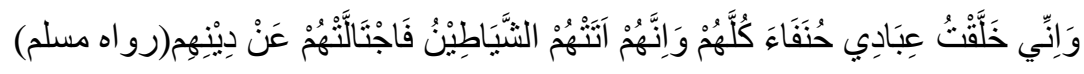

Artinya: Sesungguhnya telah kuciptakan hamba-hambaku itu berwataq hanif. Kemudian setan datang kepada mereka, maka disesatkannya mereka dari agama mereka. (HR. Muslim)

\section{C.7 Asas Manajemen}

Asas-asas umum manajemen (general principles of management), adalah :

1) Divinision of work (asas pembagian kerja)

Asas ini sangat penting, karena adanya limit factors, artinya adanya keterbatasan-keterbatasan manusia dalam mengerjakan semua pekerjaan. Keterbatasan-keterbatasan ini mengharuskan diadakannya pembagian pekerjaan. Tujuannya untuk memperoleh efisiensi organisasi dan pembagian kerja yang berdasarkan spesialisasi sangat diperlukan, baik pada bidang teknis maupun pada bidang kepemimpinan.

Asas pembagian kerja ini mutlak harus diadakan pada setiap organisasi karena tanpa pembagian kerja berarti tidak ada organisasi dan kerja sama diantara anggotanya.

2) Authority and Responsibility (asas wewenang dan tanggung jawab)

Menurut asas ini perlu adanya pembagian wewenang dan tanggung jawab antara atasan dan bawahan; wewenang harus seimbang dengan tanggung jawab. Al-Munzir Vol. 12. No. 1 Mei 2019 
3) Discipline (asas disiplin)

Menurut asas ini, hendaknya semua perjanjian, peraturan yang telah ditetapkan, dan perintah atasan harus dihormati, dipatuhi, serta dilaksanakan sepenuhnya.

4) Unity of Command (asas kesatuan perintah)

Menurut asas ini, hendaknya setiap bawahan hanya menerima perintah dari seorang atasan dan bertanggungjawab hanya kepada seorang atasan pula. Tetapi setiap atasan dapat memberi perintah kepada beberapa orang bawahan.

5) Unity of Direction (asas kesatuan jurusan atau arah)

Setiap orang (kelompok) bawahan hanya mempunyai satu rencana, satu tujuan, satu perintah dan satu atasan, supaya terwujud kesatuan arah, kesatuan gerak dan kesatuan tindakan menuju sasaran yang sama.

6) Subordination of Individual Interest into General Interest (asas

kepentingan umum di atas kepentingan pribadi)

Setiap orang dalam organisasi harus mengutamakan kepentingan bersama (organisasi), di atas kepentingan pribadi.

7) Remuneration of Personnel (asas pembagian gaji yang wajar)

Menurut asas ini, hendaknya gaji dan jaminan-jaminan sosial harus adil, wajar, dan seimbang dengan kebutuhan, sehingga memberikan kepuasan yang maksimal baik karyawan maupun majikan.

8) Centralization (asas pemusatan wewenang)

Setiap organisasi harus mempunyai pusat wewenang, artinya wewenang itu dipusatkan atau dibagi-bagikan tanpa mengabaikan situasi-situasi khas, yang memberikan hasil keseluruhan yang memuaskan. Centralization ini sifatnya dalam arti relatif, bukan absolut (mutlak).

9) Scalar of Chain (asas hierarki atau asas rantai berkala)

Saluran perintah yang mengalir dari atas ke bawah harus merupakan mata rantai vertikal yang jelas, tidak terputus, dan dengan jarak terpendek. Maksudnya perintah harus berjenjang dari jabatan tertinggi ke jabatan terendah dengan cara yang berurutan.

10) Order (asas keteraturan) 
Asas ini dibagi atas material order dan social order, artinya keteraturan dan ketertiban dalam penempatan barang-barang dan karyawan.

11) Equity (asas keadilan)

Pemimpin harus berlaku adil terhadap semua karyawan dalam pemberian gaji dan jaminan sosial, pekerjaan dan hukuman. Perlakuan yang adil akan mendorong bawahan mematuhi perintah-perintah atasan dan gairah kerja.

12) Initiative (asas inisiatif)

Menurut asas ini, seorang pemimpin harus memberikan dorongan dan kesempatan kepada bawahannya untuk berinisiatif, dengan memberikan kebebasan agar bawahan secara aktif memikirkan dan menyelesaikan sendiri tugas-tugasnya.

13) Esprit de Corps (Asas Kesatuan)

Menurut ini, kesatuan kelompok harus dikembangkan dan dibina melalui sistem komunikasi yang baik, sehingga terwujud kekompakkan kerja (team work)dan timbul keinginan untuk mencapai hasil yang baik.

14) Stability of Turn-over of Personnel (Kestabilan Jabatan Karyawan)

Menurut asas ini, pimpinan perusahaan harus berusaha agar mutasi dan keluar masuknya karyawan tidak terlalu sering, karena akan mengakibatkan ketidakstabilan organisasi, biaya-biaya semakin besar, dan perusahaan tidak tidak mendapat karyawan yang berpengalaman.

\section{C.8 Asas Manajemen Dakwah}

Asas Manajemen Dakwah antara lain (1)Asas Konsolidasi. Asas ini mengandung makna bahwa setiap organisasi dakwah harus selalu dalam keadaan mantap dan stabil, jauh dari konflik, dan terhindar dari perpecahan, baik lahiriah maupun batiniah. (2) Asas koordinasi Asas ini berarti organisasi dakwah harus mampu memperlihatkan kesatuan gerak dan satu komando. (3) Asas Tajdid, Asas ini memberi pesan bahwa oeganisasi dakwah harus selalu tampil prima dan energik, penuh vitalitas dan inovatif. (4) Asas Ijtihad, merupakan aktivitas akademik dan intelektual yang hanya bisa dilakukan oleh para ulama dan cendikiawan muslim. (5) Asas Pendanaan dan Kaderisasi. Asas ini mengingatkan bahwa setiap organisasi dakwah harus berusaha mendapatkan dukungan dana Al-Munzir Vol. 12. No. 1 Mei 2019 
yang realistic dan diusahakan secara mandiri dari sumber-sumber yang halal dan tidak mengingat. (6) Asas Komunikasi, asas ini memberikan arah bahwa setiap organisasi dakwah, pengelolaannya harus komunikatif dan persuasif, karena dakwah sifatnya mengajak bukan mengejek, dakwah itu harus sejuk dan memikat. (7) Asas Tabsyir dan Taisir, Kegiatan dakwah harus dilaksanakan dengan prinsip menggembirakan dan mudah. (7) Asas Integral dan Komprehensif, Asas ini mengingatkan kepada kita bahwa pelaksanaan kegiatan dakwah tidak hanya terpusat di masjid atau di lembaga-lembaga keagamaan semata, akan tetapi harus terintegrasi dalam kehidupan umat dan menyentuh kebutuhan yang menyeluruhn dari segenap strata sosial masyarakat, baik birokrat atau penguasa maupun lapisan elite ekonomi dan masyarakat marginal. (8) Asas penelitian dan pengembanngan, Kompleksitas permasalahan umat harus menjadi kajian dakwah yang mendalam, karena dakwah akan gagal bila saja sudut pandang hanya terpusat pada satu sisi saja, sementara komunitas masyarakat lainnya terabaikan. (9) Asas Sabar dan Istiqomah Bersaing dengan kemajuan ilmu pengetahuan dan teknologi informasi, sering membuat dakwah menemui jalan buntu bahkan melelahkan. Kelelahan tanpa disadari dapat menghilangkan kesabaran dan merusak nilai-nilai istiqomah. Di saat-saat seperti itulah prinsip sabar dan istiqomah perlu disegarkan untuk diaktualisasikan melalui berbagai kegiatan dakwah.

\section{C.9 Manajemen Dakwah Ldk Upmi Iain Kendari}

\section{1) Perencanaan Dakwah}

LDK UPMI IAIN Kendari merupakan salah satu lembaga dakwah yang ada dan bergerak di kampus, khususnya di kampus IAIN Kendari. Tujuan yang ingin dicapai oleh LDK UPMI IAIN Kendari adalah menjadikan mahasiswa dan mahasiswi IAIN Kendari sholih-sholihah, berpikir, dan berkepribadian Islami.

Tujuan LDK UPMI adalah ingin menjadikan mahasiswa dan mahasiswi IAIN Kendari sholih-sholihah, berpikir, dan berkepribadian Islami. Beliau menambahkan, LDK UPMI juga ingin menjadi bagian dari lembaga dakwah kampus yang ikut serta dan aktiv dalam melakukan pembinaan kepada mahasiswa dan mahasiswi IAIN Kendari untuk terwujudnya tujuan dakwah LDK UPMI serta terwujudnya kampus yang Islami.Dalam mewujudkan tujuan dakwah yamg ingin 
dicapai oleh LDK UPMI IAIN Kendari, LDK UPMI melakukan dialog bersama mahasiswa, melakukan seminar-seminar dan lain sebagainya yang telah direncanakan sebelumnya dan dituangkan ke dalam program kerja LDK UPMI IAIN Kendari.

Cara yang digunakan oleh LDK UPMI untuk mencapai tujuan yang telah di tetapkan tersebut, yakni menjadikan mahasiswa dan mahasiswi IAIN Kendari sholih-sholihah, berpikir, dan berkepribadian Islami, adalah dengan melakukan dialog bersama msyarakat kampus, khususnya kepada mahasiswa dan mahasiswi IAIN Kendari, melakukan seminar-seminar dan lain sebagainya yang telah di rencanakan sebelumnya, yang telah ditungkan ke dalam program kerja.

Dalam pembuatan program kerja, LDK UPMI IAIN Kendari melakukan musyawarah terlebih dahulu. Berdasarkan wawancara penulis dengan sekretaris umum LDK UPMI, yakni saudara Fathul, beliau menjelaskan bahwa proses pembuatan program kerja ini dengan melakukan rapat ataupun musyawarah pembentukan program kerja. Lanjut beliau, setiap divisi di intruksikan oleh ketua LDK UPMI untuk membuat program kerja. Kemudian, program kerja yang telah dibentuk oleh masing-masing divisi akan diserahkan kepada ketua untuk selanjutnya diseleksi, mana program yang akan dijalankan dimasa yang akan datang.

Dalam pelaksanaan program kerja, LDK UPMI dibantu pendanaan dari anggaran yang disediakan oleh pihak kampus. Dalam pelaksanaan program kerja yang telah disusun sebelumnya, tentu membutuhkan dana yang cukup besar. Selain itu, sumber dana LDK juga berasal dari infak para kader LDK dan dari upaya para kader LDK seperti melakukan bazaar.

\section{2)Pengorganisasian Dakwah}

LDK Al-Karamah dijalankan oleh sistem kepengurusan yang terdiri dari ketua, sekretaris, bendahara, serta berbagai divisi seperti divisi pembinaan, divisi syiar dan opini, divisi infokom, dan divisi keakhwatan. Ketua adalah jabatan tertinggi di dalam kepengurusan LDK UPMI IAIN Kendari yang bertugas memimpin LDK UPMI IAIN Kendari.Sekeretaris adalah jabatan yang bertanggung jawab langsung kepada Ketua Umum LDK UPMI dan bertugas membantu Ketua Umum dalam menjalankan tugasnya. Tugas sekretaris LDK Al-Munzir Vol. 12. No. 1 Mei 2019 
UPMI IAIN Kendari adalah: 2(1) Menerima Surat Masuk dan Surat Keluar beserta membuat laporannya secara berkala. (2) Mengontrol Absensi anggota pada setiap kegiatan rapat dan kegiatan sejenisnya. (3) Mengontrol Keberadaan berkas-berkas LDK UPMI baik yang bersifat penting maupun biasa. (4) Membuat proposal pada kegiatan yang diadakan LDK UPMI. Bendahara adalah jabatan yang bertanggung jawab langsung kepada ketua mengenai pengelolaan keuangan LDK UPMI IAIN Kendari. Tugas bendahara secara umum adalah bertanggung jawab terhadap penggunaan dan pengelolaan keuangan.

Divisi Pembinaan salah satu bagian atau seksi dari Lembaga Dakwah Kampus UPMI IAIN Kendari yang secara umum mempunyai tugas pokok memberikan pengembangan dan regenerasi demi terciptanya pembinaan yang menyeluruh di kampus. Selain itu Divisi Pembinaan juga mensosialisaikan kegiatan-kegiatan lembaga sehingga mahasiswa-mahasiswa dapat tercerahkan menuju kampus Islami seperti yang diharapkan institusi ini.

Divisi Syiar dan Opini adalah salah satu bagian dari Lembaga Dakwah Kampus IAIN Kendari yang secara umum mempunyai tugas pokok: mensyiarkan segala hal yang berkaitan dengan lembaga dakwah kampus baik dalam dunia nyata maupun melalui tekhnologi sosial media.

Divisi Infokom adalah salah satu bagian dari Lembaga Dakwah Kampus UPMI IAIN Kendari yang secara umum bertugas: menyampaikan, memberitakan dan mensosialisasikan LDK UPMI sebagai Lembaga Dakwah Kampus yang berfungsi sebagai pengontrol dan pelaksana kegiatan mahasiswa yang berlandaskan Syariat Islam yang menyeluruh.

Divisi Keakhwatan adalah salah satu bagian dari Lembaga Dakwah Kampus IAIN Kendari yang secara umum bertugas memberikan programprogram kerja untuk menambah tsaqofah bagi mahasiswi IAIN Kendari.

Selain itu LDK UPMI juga memiliki dewan penanggung jawab dan pembina yang terdiri atas Rektor IAIN Kendari, wakil Rektor IAIN Kendari, Dosen-dosen IAIN Kendari dan ulama/ustadz yang dipilih oleh dewan Pengkaji dan Penimbang (DPP), dalam hal ini Senior-senior LDK UPMI IAIN Kendari yang telah menamatkan pendidikan S1 atau masih kuliah (S2/S3) dan/atau masih bermukim di Kendari. Dewan pembina bertugas memberikan saran dan nasehat serta bantuan kepada LDK UPMI IAIN Kendari. 


\section{3) Pergerakan Dakwah}

Untuk terealisasinya kegiatan-kegiatan yang telah direncanakan, LDK UPMI melakukan penggerakan kepada para anggotanya. Adapun cara yang digunakan oleh LDK UPMI untuk menggerakkan anggotanya agar melaksanakan rangkaian kegiatan mengguanakan beberapa cara. Sebagaimana yang disampaikan oleh beberapa pengurus LDK UPMI IAIN Kendari.

Agus menyatakan, dalam menggerakkan anggota, ketua memberikan instruksi kepada para anggotanya dalam berbagai macam tugas yang telah direncanakan sebelumnya. Ketua juga mengikutsertakan para anggota dalam mengambil sebuah keputusan yang berhubungan langsung dengan organisasi.

Selain itu ketua juga memberikan bimbingan dan motivasi kepada para anggotanya. Dalam menggerakkan anggota, ketua juga membimbing anggotanya agar dapat melaksanakan tugas yang akan mereka emban. Selain itu, atasan juga memberikan motivasi dan penyemangat dakwah yang diambil dari alquran dan hadits-hadits Nabi saw., serta dari para ulama dan lain sebagainya.

\section{4) Pengawasan Dakwah}

Di dalam organisasi LDK UPMI, yang bertugas melakukan pengawsan adalah ketua umum dan setiap ketua divisi. Sebagaimana yang disampaikan oleh Agys, ketua LDK UPMI, bahwa yang bertugas melakukan pengawsan adalah ketua umum. Dengan menanyakan langsung ketika mengadakan rapat, mengenai tugas yang diberikan, apakah sudah dilaksanakan atau belum, serta kendala apa yang ditemui. Selain itu, di setiap selesai melaksanakan sebuah kegiatan seperti seminar yang diadakan oleh LDK, panitia juga diminta untuk membuat laporan tertulis. Begitu juga setiap akhir masa kepengurusan, setiap divisi diintruksikan untuk membuat laporan pertanggung jawaban. Tambahnya, dan setiap ketua divisi juga melakukan kontrol kepada anggotanya. Sementara itu ketua umum beserta seluruh jajaranya juga diawasi oleh DPP (Dewan Pengkaji dan Penimbang) LDK UPMI IAIN Kendari.

\section{Penutup}

Temuan penelitian ini adalah bahwa manajemen dakwah LDK UPMI IAIN Kendari telah sepenuhnya berjalan sesuai konsep dan peinsip dasar 
manajemen Yakni, Adanya perencanaan Dakwah, pengorganisasian dakwah, pergerakan dakwah dan pengawasan dakwah.

\section{Daftar Pustaka}

Abd. Rosyad Shaleh, Manajemen Dakwah Islam, Jakarta: Bulan Bintang, 1977

Abdul Aziz, Islah al-Wakhudu al-Diniy, Mesir: Attiqarah al-Kubra, 1997

AD/ART (Lembaga Dakwah Kampus-Unit Pengkajian Mahasiswa Islam (LDKUPMI): 2013

Ahmad Subandi, Ilmu Dakwah Pengantar Kearah Metodologi, Bandung: Yayasan Syahida, 1994.

Asmuni Syukir, Dasar-dasar Strategi Dakwah Islam, Surabaya: Al-Ikhlas, 1983

Brantas, Dasar-dasar Manajemen, Alfabeta, Bandung, 2009

G. R. Terry, Principles of Management, Georgetown: Richard D. Irwing Inc., 6 th Edition, 1972

H. Malayu, Hasibuan, Manajemen Dasar Pengertian dan Masalah, Jakarta: Bumi Aksara, Cet. 8, 2009

H. Zainal Muchtarom, Dasar-dasar Manajemen Dakwah, Yogyakarta: Al-Amin

H. M. Anton Athoillah, Dasar-dasar Manajemen, Bandung: CV Pustaka Setia, Cet. 1, 2010

Hafi Anshari, Pemahaman dan Pengamalan Dakwah, Surabaya: Al-Ikhlas, 1993

Jamaluddin Kafie, Psikologi Dakwah, Surabaya: Indah Surabaya, 1993

Kementerian Agama RI. Al-Quran Dan Terjemahannya. Jakarta: Direktorat Urusan Agama Dan Pembinaan Syariah, 2012.

Kementerian Agama RI, Al-Qur'an dan Terjemahan New Cordova, cet I (Bandung: Syaamil Quran. 2012

M. Munir, Manajemen Dakwah, Jakarta: Rahmat Semesta, 2009.

Muhamad Arifin. Dakwah Multi Media, Surabaya : Graha Media, 2006.

RB. Khatib Pahlawan Kayo, Manajemen Dakwah dari Dakwah Konvensional Menuju Dakwah Professional, Jakarta: Amzah, Cet. 1, 2007

Toha Yahya. Ilmu Dakwah, Jakarta :Wijaya, 1971. 
Al-Munzir Vol. 12. No. 1 Mei 2019 